\title{
Application of Multidimensional Scaling in Determining the Competition Position Among Schools in Manado
}

\author{
Deisi Natalia Maapanawang*, Santje Salajang, Wayan Damai \\ Master program in Mathematics Education \\ Manado State University \\ Tomohon, Indonesia \\ *dmaapanawang@gmail.com, santjesalajang@unima.ac.id, iwayandamai@unima.ac.id
}

\begin{abstract}
Senior High School are in charge of education and teaching for human resource development. There are 57 senior high school in Manado. However, there are still many new private senior high school. This causes more intens competition among senior high school in Manado to win over consumers (students). Based on these considerations, this research was conducted with the aim to find out the competitive position map among high schools in Manado. The research types in this research is a survey research. The statistical method in this research is Multidimensional scaling. Multidimensional scalling is a part of multivariate. The sample of this study was 303 students who were in 8 high schools, namely Eben Haezar Christian High School, Don Bosco Catholic High School, Rex Mundi Catholic High School, State High School 9, Prisma Pioneer High School, State High School 1, MAN Model 1, and MAS Al Muhajirin. The results of the study were reviewed from 9 variables including: the cost of education, location, teacher, school management, religion, facilities or infrastructure, graduates, reputation and promotion. The results show the map of competitiveness among high school in Manado. It is showed that the closest competitors are SMA Negeri 1 Manado are MAN Model 1 Manado and SMA Prisma Pioneer Manado. While the closest competitor of Manado 9 Public High School is MAS Al Muhajirin Manado. Meanwhile, private schools that compete closely with each other are Eben Haezar Manado Christian High School and Don Bosco Manado Catholic High School. While the Rex Mundi Catholic High School in Manado is considered to have no competitors. These current findings support that the multidimensional is powerful tool for estimating the school position among group.
\end{abstract}

Keywords: multidimensional scaling, school competition, perception maps

\section{INTRODUCTION}

Proper and good education is very important for every individual. Without education, the quality of oneself will also be very low, which will also affect the quality of the nation and state. Considering the importance of education for every people. This is also sated in the constitution which states that every citizen has the right to education and every citizen is obliged to attend basic education, the role of educational institutions is needed [1].

One example of an educational institution is a formal education institution. Formal education plays an important role in providing education in a structured and tiered manner to their students. Senior High School (SMA) is part of formal educational institutions that are in charge of education and teaching for the development of human resources. The development of society today demands intense competition between high schools. This makes every high school must be able to deal with developing programs, including by keeping the school's image always good.

The North Sulawesi Manado Education Office stated that the number of SMA in Manado was 57. Although there are quite a lot of SMA in Manado, there are still more and more new private high schools, this causes increasingly intense competition between high schools in Manado to win consumers (students) because the presence of students is an important asset for the sustainability or existence of a school.

In facing this competition, the accuracy of the school management in making decisions to support the success of the school is very important. School management is in need of complete and accurate information data that is relevant to this problem. In solving the problem of determining the position of competition between high schools, it is needed a technique or method to analyze data, especially methods that are easy to use and interpret the conclusions. One statistical technique that can help to find out the position map between high schools is to use multidimensional scaling analysis (MDS).

Multidimensional scaling analysis is part of multivariate analysis which aims to find the relationship between several objects by only looking at the estimated distance between objects or by looking at the spatial map produced that represents respondents' perceptions [2]. By using the MDS method, the resulting solution is easier to understand so that MDS has been used in various fields of research.

Related to the problem of determining position in competition between high schools, it turns out that many things 
can affect competition between high schools. The quality of schools both in terms of facilities and infrastructure as well as teaching staff is a consideration. For this reason, it is necessary to conduct research concerning competition among MA in Manado by taking into account several factors that influence competition, including the cost of education, facilities and infrastructure, teaching staff, graduates, etc.

\section{RESEARCH METHODS}

This research uses survey research methods. The statistical method used in this research is multidimensional scaling analysis (MDS) [3,4] which analysis using SPSS statistical software's. The research site in the form of questionnaire data collection was carried out in 8 high schools that have good UN scores in Manado, and data analysis was carried out at the Manado State University Postgraduate Program located in Kaaten, Tomohon, in July 2019.

The population in this study were all high school students with active status in Manado in the odd semester of the 20192020 Academic Year. The research sample is high school which entered the top 10 of UNBK in the 2017-2018 school year and was popular in the community. Determination of the sample in this study using a purposive sampling technique, i.e. the sample was chosen based on certain considerations and objectives, with the determination of sample size using the Slovin formula [5].

The variables that will be observed in this study are 9 variables, namely the cost of education, location, teachers, school management, religion, facilities or infrastructure, graduates, school reputation/ image and promotion. This research uses primary data and secondary data.

Primary data were obtained by distributing questionnaires to respondents (students) in 8 schools in Manado. Meanwhile, secondary data in the form of data obtained from the North Sulawesi Manado Education Office website about the number of high schools in Manado, and data from the Ministry of Education and Culture about high schools in Manado that have good UN scores, in the 2017/2018 school year and the number of students active in 8 public and private high schools.

The research instruments that will be used first are content validation by the experts and then tested through a preliminary survey by distributing questionnaires to 20 students in SMA Negeri 9 Manado. Then the validity and reliability tests are performed before being used as a research instrument.

\section{RESULTS AND DISCUSSION}

Based on the derived stimulus or perception map of High Schools (SMA) in Manado, it is seen that quadrant I is only occupied by Rex Mundi Catholic High School in Manado, while quadrant II is occupied by Prisma Pioneer Manado High School together with Manado 1 MAN High School and Manado MAN Model 1.

Although Prisma Pioneer Manado, SMA 1 and MAN Model 1 Manado are in one quadrant, but the position of
Prisma Pioneer Manado SMA is quite far away compared to Manado 1 MAN and Manado MAN Model 1.

This means that there is competition between the three high schools, but the fiercest competition is Manado 1 Manado and MAN Model 1 Manado, this is because these two schools are public schools and excel in education costs.

Quadrant III position is occupied by Manado 9 Public High School and Mas Al Muhajirin Manado, while in Quadrant IV is occupied by all private schools namely Eben Haezar Manado Christian High School and Don Bosco Manado Catholic High School.

Objects that are close to one another are perceived as having similarities. For example, SMA Negeri 1 Manado and MAN Model 1 Manado, Mas Al Muhajirin Manado and SMA Negeri 9 Manado and Eben Haezar Manado Christian High School and Don Bosco Manado Catholic High School are all plotted close together which means the respondent perceives similarities between SMA Negeri 1 Manado and MAN Model 1, MAS Al Muhajirin Manado and Manado 9 Public High School and between Manado Eben Haezar Christian High School and Don Bosco Manado Catholic High School.

Conversely there is a wide gap between the Rex Mundi Manado Catholic High School and Don Bosco Manado Catholic High School which means there is a perception of dissimilarity between the two high schools. In this study, researchers also analyzed dimensional configurations. In dimension 1, the horizontal dimension separates Prisma High School, SMA 1, MAN, SMA 9 and Mas Al Muhajirin (on the left of the map) from the Eben, Don Bosco and Rex Mundi high schools.

Dimension 1 illustrates the dimensions of education costs or the level of expensiveness of education costs with relatively inexpensive on the negative (left) dimension 1 and expensive on the positive (right) dimension 1. The same characteristics between SMA Prisma, SMA 1, MAN, SMA 9 and MAS Al Muhajirin is that the five high schools are superior in terms of cost (the cost of education is relatively affordable), this is because 3 of the five schools are public schools.

From the analysis also found that the order of high school positions that received good or positive responses to those not so good from students based on the cost of education, location, teachers, management of religious schools, facilities or infrastructure, graduates, reputation and promotion, are as follows: : (1) Manado Rex Mundi Catholic High School, (2) Manado Eben Haezar Christian High School and Don Bosco Manado Catholic High School, (3) Prisma Pioneer Manado High School, Manado State High School 1 Manado and MAN Model 1 Manado, (4) Manado 9 Public High School and Mas Al Muhajirin Manado.

The first rank is occupied by Rex Mundi Catholic High School in Manado, because based on image 2 the position of Rex Mundi Catholic High School in Manado is in dimension 1 $\&$ dimension 2 of the positive part, while for SMA Negeri 9 Manado and MAS Al Muhajirin Manado is in dimension 1 in negative part and dimension 2 negative part. 
are no high schools that have the closest position to the Rex Mundi Catholic High School in Manado. These results suggesting that multidimensional scaling provides proper map of school competitiveness among high school in Manado.

\section{REFERENCES} position map of the competitiveness among school. Here the scaling was conducting on 9 variables including: education costs, location, teachers, school management, religion, facilities or infrastructure, graduates, reputation and promotion. From this current result, it can be concluded that the closest competitors of SMA Negeri 1 Manado are MAN Model 1 Manado and SMA Prisma Pioneer Manado. In addition, the closest competitor of Manado 9 Public High School is MAS Al Muhajirin Manado. In case of private schools, it is found that the school that competing each other are the Eben Haezar Christian High School in Manado and the Don Bosco Catholic High School in Manado.

In contrast, the Rex Mundi Catholic High School in Manado is considered to have no competitors, because there
[1] A.W. Hubsch, Education and self-government: The right to education under state constitutional law. JL \& Educ., 18, 93, 1989.

[2] M.A. Cox and T.F. Cox, Multidimensional scaling. In Handbook of data visualization (pp. 315-347). Springer, Berlin, Heidelberg, 2008.

[3] I. Borg and P. Groenen, "Modern multidimensional scaling: Theory and applications," Journal of Educational Measurement, vol. 40, no. 3, pp. 277-280, 2003.

[4] H.I. Ghozali, Book: Multivariate Analysis Application with IBM SPSS 23. Diponegoro University Publisher Agency. Semarang, 2016.

[5] K. Wardati, E.D. Supandi and I. Kuswidi, "Research Journal: Segmentation Analysis and Position Map of UIN Sunan Kalijaga against Higher Education in Yogyakarta Using Dimensional Scalling Method," Penagama, nol. XIX, no. 2, 2010. 